Review Article

www.ijrap.net

\title{
CLINICAL APPROACH TO AVARANA
}

Praveen B S*

Assistant Professor, Dept of PG Studies in Panchakarma, SDM College of Ayurveda \& Hospital, Thanniruhalla, B M Road, Hassan, Karnataka, India

Received on: 19/08/12 Revised on: 22/10/12 Accepted on: 06/11/12

\author{
*Corresponding author \\ E-mail: praveenbs29@rediffmail.com \\ DOI: 10.7897/2277-4343.03612 \\ Published by Moksha Publishing House. Website www.mokshaph.com \\ All rights reserved.
}

\section{ABSTRACT}

Avarana is one of the most difficult concepts to understand, teach and incorporate in clinical practice. It is either least observed or goes unidentified due to lack of skill. To understand and analyze the Avarana, meticulous knowledge of basic concepts of Ayurveda is essential. Panchakarma as well as other varieties of treatments has to be advocated based on the Avruta and Avaraka. Observation of the symptoms of the Avaraka and Avruta is mandatory to get succeed in the treatment. The treatment of Avarana should aim towards cleansing the Srotas with different medicaments which possess Anabhishyandhi, Snigdha, Kapha Pitta Aviruddham and Vatanulomana Dravya. Administration of Yapana Basti, Sramsana chikitsa and Rasayana Dravya may be considered after analyzing the Bala of patient. Though Panchakarma is not been considered as the treatment of choice in all varieties of Avarana, in specific Avarana it may be utilized with maximum benefits. The concept of Avarana is still relevant to present era. Different clinical conditions present like Avarana, depending on the stage of the disease. Treatment of Avarana is easy, provided diagnosis is impeccable.

Key words: Avarana, Avruta, Avaraka, Panchakarma, Rasayana

\section{INTRODUCTION}

Ayurveda believes in different pathology which sets in different Srotas to produce different diseases. Whenever a favorable condition and situation arises, disease will manifest. It is elucidated that Ati Pravrutti, Sangha, Vimarga Gamana and Sira Granthi are different varieties of Sroto Dushthi which results in to diseases. Nanatmaja Vikara, Anubhanda, Gata Vata and Avarana are different pathologies explained in Ayurveda. Avarana is one of the most difficult concepts to understand, teach and incorporate in clinical practice. It is either least observed, diagnosed or goes unidentified due to lack of skill. To understand and analyze the Avarana, meticulous knowledge of basic concepts of Ayurveda is essential. Misunderstandings on Avarana are many. It is assumed that each and every disease manifest due to Avarana and there is no difference between anubhanda and Avarana. In fact knowledge of Avarana plays an integral part in understanding the Samprapti of many diseases. Famous saying in Ayurveda convey that, Samprapti Vighatana itself is the management of disease. So diagnosis plays an important part in treating Avarana. Panchakarma and Rasayana play an integral role in the management of Avarana. Panchakarma treatment modalities need to be selected very carefully as faulty selection leads to failure.

\section{Concept of Avarana}

Vata Vyadhi can manifest either due to Dhatu Kshaya or Avarana. ${ }^{1}$ Avarana literally means obstruction or to cover. Vata generally possesses the quality of Chala which is responsible for all its function. If Vata gets obstructed then, its function gets hampered and results in to Vata Vyadhi. Many scattered references about Avarana are available in classics apart from Vata Vyadhi Chapter. Either Vruddhi or Kshaya of certain Dhatu can produce Avarana. Vata Rakta is an instance for the pathology in which Vriddhi of certain Dhatu produce Avarana. ${ }^{2}$ Dhatu Kshaya generally results in formation of Anyonya Avarana.

It is not only the Vata which gets obstructed and results in diseases. Pitta also may get obstructed by Kapha and produce disorder like Shakhashrita Kamala. ${ }^{3}$ Ayurveda believes in Pancha Mahabhuta concepts as basic principle to understand the physiology as well as pathology. Tridosha theory is the simplified form of the same. Collaborated Vayu and Akasha are considered as Vata. Agni is considered as Pitta and Pritvi along with Jala is considered as Kapha. Vata Dosha is lightest among all, Pitta is lighter and Kapha is heavy by nature. Vata Possess Chala Guna, Pitta posseses Sara Guna and Kapha Possesses Sthira Guna. As Kapha is heavier as compared to other two, it naturally tends to obstruct Vata and Pitta. Pitta is heavier than Vata due to its Drava Guna, it can obstruct Vata. So Vata is the only Dosha which tends to get obstructed easily most of the time. Different varieties of Vata move in different directions due to which a particular variety of Vata may get obstructed by each another. Prana and Udana naturally moves upwards, Samana moves in lateral direction, Apana moves downward and tendancy of Vyana is to move in all directions. Though Prana and Udana as well as Samana and Apana work in coordination it may obstruct each other due to minor variation in path.

The concept of Avarana can be well understood with some simple examples. In a traffic signal if heavy vehicles are placed at front then, smaller vehicles get obstructed and can not move front. Whereas, a smaller vehicle like motor bike can move from far behind till front in smaller passages through available space but will get obstructed finally. Similar pathology can be understood in Anya Avarana. Where as in a traffic signal two or multiple vehicles moving in different directions 
violating traffic rules, lands in collision and ends in disaster. Similar pathogenesis occurs in Anyonya Avarana. Anubhanda of a Dosha is mere collaborative effect of both Dosha where symptoms of both the Dosha are clearly evident. Where as, in an Avarana two or more entities obstruct each other and results in disease. For understanding the concept of Avarana it is mandatory to understand Avaraka and Avruta. When Dosha or Dhatu obstructs a particular Dosha then, it will give rise to increased signs and symptoms related to the function of that particular Dosha or Dhatu which has obstructed. ${ }^{4}$ The entity which get obstructed will show less signs and symptoms related to its normal functions. For instance, If Pitta obstructs Vata then person will suffer with Daha, Trushna, Shula, Bhrama, Tama, Vidaha and Sheeta Kamata which are symptoms of Pitta and Karmahani is observed which is a Vata symptom. ${ }^{5}$

Commonly confronted Anya Avarana is Vidavruta Vata which is characterized by Vibhandha, Anaha, Shushka Vit Pravartana, Shroni Vankshana Prushtha Ruk, Viloma gati of Vata. This variety of Anya Avarana is easiest Avarana to understand. ${ }^{6}$ Different Dhatu or Mala can also obstruct specific variety of Vata. For instance, in Pittavruta Prana vata, Murcha, Daha, Bhrama, Shula, Vidaha, Sheeta Kamita and Chardhana are the presenting symptoms. ${ }^{7}$ In Kaphavruta Vyana either Gati Sanga or Adhika Gati or both may be observed. ${ }^{8}$ In Anyonya Avarana the symptoms and signs observed are related to two different varieties of Vata. For instance, in Pranavruta Vyana Vata, Sarvendriya Shunyatvam, Smruti Bala Kshayam are observed symptoms. ${ }^{9}$ So the permutation and combinations of the Avarana are many. Acharya have explained many Avarana and its signs and symptoms in detail. Further it is indicated that if unknown Avarana is suspected then, observation of signs and symptoms will give clue to the diagnosis of Avarana. The increased signs and symptoms will suggest the Avaraka and decreased signs and symptoms suggest Avruta. ${ }^{10}$ Once the case is diagnosed then the treatment is predictable. Faulty treatments protocol may lead to failure.

References are available regarding the Avarana as pathology in different disorders. Medasavruta Vata also known as Adhya Vata or Vatarakta is one such condition. ${ }^{11}$ Kaphadhika Vatarakta mimics the features of Medasavruta Vata. More over Urusthambha is also been considered as Medasavruta Vata. ${ }^{12}$ Pathogenesis of Kasa is also due the Avarana between Prana Vata and Udana Vata. ${ }^{13}$ Prameha is also another disorder in which Avarana is a variety of pathology apart from Dhatu Kshaya. ${ }^{14}$ Similarly many disorders are produced as a result of Avarana. More than one entity also can create Avarana to the other Dosha. So identification of Avarana becomes very essential. In the pathogenesis of Avarana, Ati Pravrutti leads to Sangha and it in turn leads to Vimarga Gamana. So it may produce grave complications like Hridroga, Vidhradhi, Pleeha, Gulma and Atisara if unnoticed and treated improperly. ${ }^{15}$ So stupendous skills are required to the Ayurvedic physician to diagnose and treat the Avarana successfully.

\section{Treatment principles of Avarana}

The treatment of Avarana should aim towards cleansing the Srotas with different medicaments which possess Anabhishyandhi, Snigdha, Kapha Pitta Aviruddham and Vatanulomana property. ${ }^{16}$ Administration of the Yapana Basti, Sramsana chikitsa and Rasayana Dravya may be considered after analyzing the Bala of patient and stage of the disease. ${ }^{17}$ Anya Avarana can be treated successfully after adapting these treatment modalities, whereas treatment of Anyoanya Avarana is not simple.

In Anyonya Avarana, different varieties of Vata should be directed in their respective direction. Udana Vata should be directed up; Samana Vata should be directed towards lateral direction. Apana Vata should be put back in downward direction where as Vyana Vata should be put back in its normal direction. Prana Vata should be protected with due respect, which ever treatment is been planned. ${ }^{18}$ Different varieties of Panchakarma treatments are planned in order to remove the obstruction and put the specific variety of Vata in its own path.

\section{Panchakarma in Avarana}

Though Panchakarma is not been considered as the treatment of choice in all varieties of Avarana, in many specific Avarana different Panchakarma is the choice of treatment. For instance in Vyanavruta Prana, Sneha yukta Virechana is the choice of treatment ${ }^{19}$ and in Pranavruta Vyana, Navana Nasya is the choice of treatment. ${ }^{20}$ In Pranavruta Samana, Yapana Basti ${ }^{21}$ and in Samana Avruta Apana, Deepana Gritha is advocated. ${ }^{22}$

The selection of specific Panchakarma is aimed towards removal of Avaraka. For instance if Kapa is obstructiong Vata then, Kaphahara chikitsa should be carried out. As there are many treatment modalities which can remove Avarana of Kapha, they need to be selected based on the amount of Provoked Kapha. If Kapha is provoked too much then Vamana Karma is the natural choice. Where as, if the provoked Kapha is in moderate level other Kaphahara treatments like Udvaratana, Utsadana, Dhanyamla Dhara or Churna Pinda Sveda may be selected. Risk lies in treating the Avarana where, Kapha is obstructing Vata or specific variety of Vata as they possess different qualities. The stage when Kapha obstruction is removed, all the Kaphahara treatments have to be stopped and Vatahara treatments need to be carried out. If without proper analysis of stage of Avarana same treatment is continued then, Vata may get provoked and may lead to serious complications. So this variety of Avarana is very tricky as far as treatment is concerned.

On the contrary if Pitta is obstructing the Vata then the treatments should aim towards the removal of the Pitta Avarana. At the same time the fact of difference in the property must be bear in mind. Pitta possesses Ushna Guna where as, Vata possess Sheeta Guna. Sheeta Guna Dravya will mitigate Pitta where as Ushna Guna will mitigate Vata. Acharya have explained to perform Sheeta and Ushna Chikitsa alternatively in this variety of Avarana. ${ }^{23}$ Virechana will be a choice of treatment for both Pitta as well as Vata as, Mrudhu Shodhana is also considered as treatment of choice for even Vata. So Virechana especially Snigdha Virechana with Eranda Taila may be carried out with different Anupana. Where 
ever Virechana is difficult to perform, Mrudhu Shodhana like Sramsana may be advocated which also mitigate Vata. Sramsana is advised in almost all the Avarana, be it Anya Avarana or Anyonya Avarana. It is explained that in all the varieties of the Avarana administration of Eranda Taila is beneficial. ${ }^{24}$

Administration of Eranda Taila is been very much praised in the management of Udavarta. Depending on administration with different Anupana, Eranda Taila will remove different Avarana. ${ }^{25}$ When it is administered with Milk it mitigates Pitta, when administered with Mamsa Rasa and Yusha it mitigates Vata and When it is administered with Gomutra it mitigate Kapha. So in almost all the Avarana administration of Eranda Taila is considered as best. More over it is also found to be beneficial in different disorders like Gulma, Udara, Pleeha, Arsha, Udavarta, Yoni, Shukra Roga, Gridhrasi, Pakshaghata and Avaghada Rakta. Many out of these are considered as complications of Avarana be it Anya Avarana or Anyonya Avarana. ${ }^{26}$ Eranda Taila may be administered in the dosage as high as five Pala based on the Bala and Koshtha of the person who suffer with Avarana. Udavarta is the late complication of Vidavruta Vata in which, administration of Basti is beneficial. Basti Karma is also considered as the treatment of choice in many of the diseases. Especially Yapana Basti is considered as the choice of treatment in majority of the Avarana as it is Tridosha Hara. More over Yapana Basti can be administered in any season and time and it is devoid of complication. Erandamuladi Kshara Basti, ${ }^{27}$ Kshara Basti, Vaitarana Basti, Manjisthadi Kshara Basti, Dashamuladi Kshara Basti and Lekhana Basti may be selected in Kapha Avarana. Yapana Basti, Yastimadhu Ksheera Basti, Pancha Prasritaki Basti, Pancha Tikataka Pancha Prasritaki Basti, Manjisthadi Ksheera Basti, Guduchyadi Ksheera Basti and Piccha Basti may be administered in Pitta and Rakta Avarana. Rakta Mokshana especially Sira Vyadha also may be considered in Rakta and Pitta Avarana. In Anyonya Avarana, Chatu Prasritaki Basti, Yapana Basti, Madhu Tailika Basti, Yukta Ratha Basti, Ardha Matrika Basti, Astha Prasritaki Basti and Eranda mula Niruha Basti are beneficial.

Nasya Chikitsa may be considered where Jartrurdhva Pathology is present. Especially Shodhana Nasya like Guda Nagara and Shadbindhu Taila; Pradhamana Nasya with Katphala or Vacha and Dhuma Nasya may be selected in Kaphavrita condition. In Pittavarana or Raktavarana, Shamana Nasya like Anu Taila or Brimhana Nasya like Ksheera Bala Taila may be selected. In Either Anyonya Avarana or in Anya Avarana where the Avaraka is removed and Vata Gets exposed then, Brimhana Nasya like Go Gritha, Chaghaladi Gritha and Ksheera Bala Tailam are the choice of treatment. In Anyonya Avarana involving Prana and Udana, Nasya therapy and Murdhni Taila are choice of treatments. Tarpana Chikitsa and Karna Purana also may be considered depending on the Sthana Samshraya of the Avarana. In Avarana involving Apana Vata and Samana Vata, Vamana, Virechana and Basti are the choice of the treatment depending on the Avarana. In the context of Grahani Chikitsa, it is indicated that if the Agni Mandhya occurs due to different reasons, different treatments like Vamana, Virechana,
Basti Karma and administration of the Deepana and Pachana Gritha need to be considered. ${ }^{28}$ Same treatment principle can be adapted in the management of Avarana involving Samana and Apana Vata where, the presenting symptom is Agni Mandhya. In an Avarana involving Vyana Vata, all Panchakarma may be considered depending on the Sthana Samshraya as well as the variety of Avarana.

Rasayana Chikitsa after Panchakarma therapy is been praised in the management of the Avarana. If Kuti Praveshika Rasayana is planned then also the person need to under go Shodhana as pre operative procedure. Different Rasayana like Bharghava Prokta Rasayana, Shilajatu, Guggulu, Lashuna and Bhallataka Rasayana may be selected in different condition. ${ }^{29}$ Precautions are essential while administering Lashuna Rasayana which is contra indicated in Rakta and Pitta Avarana. More over Virechana treatment should be carried out after the administration of Lashuna Rasayana as Pitta may get provoked after prolonged administration. ${ }^{30}$

\section{DISCUSSION}

Acharya have elaborately explained different varieties of Avarana which is one of the pathology in different diseases. The concept of Avarana is still relevant to present era. Different neurological conditions and other clinical conditions present like Avarana depending on the stage of different diseases. Multiple sclerosis presents like Kaphavruta Apana or Mutravruta Apana, Axonopathy presents like Pranavruta Vyana, or Pittavruta Vyana, Axonal demyelinating poly neuropathy presents like Kaphavruta Vyana, Gullian Barre syndrome at certain stage mimics the symptoms of Pittavrita Vyana or Kaphavruta Vyana. Miniers disease mimics Pittavruta Prana, Cerebral atrophy of severe grade presents like Vyanavruta Udana, Bulbar Palsy and pseudo bulbar Palsy presents like Udanavruta Prana and central canal stenosis and carpel tunnel syndrome may present like Asthi Avruta Vata. There are many more diseases which will present like Avarana. If correctly observed and diagnosed the treatments will be quite effective. Anyonya Avarana is quite difficult to manage due to the extreme signs and symptoms and it may take long time to manage. Repeated Panchakarma and Rasayana therapy will help in different varieties of Avarana with extreme signs and symptoms.

\section{CONCLUSION}

Concept of Avarana is easy to understand provided meticulous knowledge on the basic concepts of Ayurveda is imbibed. Diagnosis plays key role in the treatments success. Panchakarma as well as other varieties of treatments has to be advocated based on the Avruta and Avaraka. Observation of the symptoms of the Avaraka and Avruta is mandatory to get succeed in the treatment. Scattered references available in the classics need to be understood and adapted in the treatment of different Avarana be it Anya Avarana of Anyonya Avarana. It is only the experience and keen observation of a clinician which will make him master in the diagnosis and treatment of Avarana. 


\section{REFERENCES}

1. Agnivesha: Charaka Samhita, with Ayurveda Deepika Teekha by Chakrapani Dutta, Published by Chaukhambha Sanskrit Sansthan, Varanasi, Edition Reprint (2004), Chikitsa Sthana: 28;199

2. Agnivesha: Charaka Samhita, with Ayurveda Deepika Teekha by Chakrapani Dutta, Published by Chaukhambha Sanskrit Sansthan, Varanasi, Edition Reprint (2004), Chikitsa Sthana: 29; 10

3. Agnivesha: Charaka Samhita, with Ayurveda Deepika Teekha by Chakrapani Dutta, Published by Chaukhambha Sanskrit Sansthan, Varanasi, Edition Reprint (2004), Chikitsa Sthana: 16; 124

4. Agnivesha: Charaka Samhita, with Ayurveda Deepika Teekha by Chakrapani Dutta, Published by Chaukhambha Sanskrit Sansthan, Varanasi, Edition Reprint (2004), Chikitsa Sthana:28;217-219

5. Agnivesha: Charaka Samhita, with Ayurveda Deepika Teekha by Chakrapani Dutta, Published by Chaukhambha Sanskrit Sansthan, Varanasi, Edition Reprint (2004), Chikitsa Sthana: 28; 61-62

6. Agnivesha: Charaka Samhita, with Ayurveda Deepika Teekha by Chakrapani Dutta, Published by Chaukhambha Sanskrit Sansthan, Varanasi, Edition Reprint (2004), Chikitsa Sthana: 28;70-72

7. Agnivesha: Charaka Samhita, with Ayurveda Deepika Teekha by Chakrapani Dutta, Published by Chaukhambha Sanskrit Sansthan, Varanasi, Edition Reprint (2004), Chikitsa Sthana: 28;221-222

8. Agnivesha: Charaka Samhita, with Ayurveda Deepika Teekha by Chakrapani Dutta, Published by Chaukhambha Sanskrit Sansthan, Varanasi, Edition Reprint (2004), Chikitsa Sthana: 28;228-229

9. Agnivesha: Charaka Samhita, with Ayurveda Deepika Teekha by Chakrapani Dutta, Published by Chaukhambha Sanskrit Sansthan, Varanasi, Edition Reprint (2004), Chikitsa Sthana: 28;202-203

10. Agnivesha: Charaka Samhita, with Ayurveda Deepika Teekha by Chakrapani Dutta, Published by Chaukhambha Sanskrit Sansthan, Varanasi, Edition Reprint (2004), Chikitsa Sthana: 28; 248

11. Agnivesha: Charaka Samhita, with Ayurveda Deepika Teekha by Chakrapani Dutta, Published by Chaukhambha Sanskrit Sansthan, Varanasi, Edition Reprint (2004), Chikitsa Sthana: 28; 65-66

12. Agnivesha: Charaka Samhita, with Ayurveda Deepika Teekha by Chakrapani Dutta, Published by Chaukhambha Sanskrit Sansthan, Varanasi, Edition Reprint (2004), Chikitsa Sthana: 27; 14

13. Agnivesha: Charaka Samhita, with Ayurveda Deepika Teekha by Chakrapani Dutta, Published by Chaukhambha Sanskrit Sansthan, Varanasi, Edition Reprint (2004), Chikitsa Sthana: 18; 6

14. Sushruta: Sushruta Samhita, with Nibhandha Sangraha theeka by Dalhana, Published by Chaukhambha Sanskrit Sansthan, Varanasi, Edition Reprint (2010), Nidhana Sthana: 6; 4

15. Agnivesha: Charaka Samhita, with Ayurveda Deepika Teekha by Chakrapani Dutta, Published by Chaukhambha Sanskrit Sansthan, Varanasi, Edition Reprint (2004), Chikitsa Sthana: 28; 236

16. Agnivesha: Charaka Samhita, with Ayurveda Deepika Teekha by Chakrapani Dutta, Published by Chaukhambha Sanskrit Sansthan, Varanasi, Edition Reprint (2004), Chikitsa Sthana: 28; 238-240
17. Agnivesha: Charaka Samhita, with Ayurveda Deepika Teekha by Chakrapani Dutta, Published by Chaukhambha Sanskrit Sansthan, Varanasi, Edition Reprint (2004), Chikitsa Sthana: 28; 240-242

18. Agnivesha: Charaka Samhita, with Ayurveda Deepika Teekha by Chakrapani Dutta, Published by Chaukhambha Sanskrit Sansthan, Varanasi, Edition Reprint (2004), Chikitsa Sthana: 28; 219-221

19. Agnivesha: Charaka Samhita, with Ayurveda Deepika Teekha by Chakrapani Dutta, Published by Chaukhambha Sanskrit Sansthan, Varanasi, Edition Reprint (2004), Chikitsa Sthana: 28; 203-204

20. Agnivesha: Charaka Samhita, with Ayurveda Deepika Teekha by Chakrapani Dutta, Published by Chaukhambha Sanskrit Sansthan, Varanasi, Edition Reprint (2004), Chikitsa Sthana: 28; 202-203

21. Agnivesha: Charaka Samhita, with Ayurveda Deepika Teekha by Chakrapani Dutta, Published by Chaukhambha Sanskrit Sansthan, Varanasi, Edition Reprint (2004), Chikitsa Sthana: 28; 204-205

22. Agnivesha: Charaka Samhita, with Ayurveda Deepika Teekha by Chakrapani Dutta, Published by Chaukhambha Sanskrit Sansthan, Varanasi, Edition Reprint (2004), Chikitsa Sthana: 28; 205-206

23. Agnivesha: Charaka Samhita, with Ayurveda Deepika Teekha by Chakrapani Dutta, Published by Chaukhambha Sanskrit Sansthan, Varanasi, Edition Reprint (2004), Chikitsa Sthana: 28; 184

24. Agnivesha: Charaka Samhita, with Ayurveda Deepika Teekha by Chakrapani Dutta, Published by Chaukhambha Sanskrit Sansthan, Varanasi, Edition Reprint (2004) Chikitsa Sthana: 13;172-173

25. Agnivesha: Charaka Samhita, with Ayurveda Deepika Teekha by Chakrapani Dutta, Published by Chaukhambha Sanskrit Sansthan, Varanasi, Edition Reprint (2004), Chikitsa Sthana: 26;27-31

26. Agnivesha: Charaka Samhita, with Ayurveda Deepika Teekha by Chakrapani Dutta, Published by Chaukhambha Sanskrit Sansthan, Varanasi, Edition Reprint (2004), Chikitsa Sthana: 26;27-29

27. Agnivesha: Charaka Samhita, with Ayurveda Deepika Teekha by Chakrapani Dutta, Published by Chaukhambha Sanskrit Sansthan, Varanasi, Edition Reprint (2004), Siddhi Sthana: 3; 41

28. Agnivesha: Charaka Samhita, with Ayurveda Deepika Teekha by Chakrapani Dutta, Published by Chaukhambha Sanskrit Sansthan, Varanasi, Edition Reprint (2004), Chikitsa Sthana: 15;207-209

29. Agnivesha: Charaka Samhita, with Ayurveda Deepika Teekha by Chakrapani Dutta, Published by Chaukhambha Sanskrit Sansthan, Varanasi, Edition Reprint (2004), Chikitsa Sthana: 28; 241-242

30. Vagbhata: Ashthanga Hridaya, Edited by Yadunandan Upadhyaya, Published by Chaukhambha Sanskrit Sansthan, Varanasi, $13^{\text {th }}$ Edition (2000), Uttara Tantra: 39;127-129

\section{Cite this article as:}

Praveen B S. Clinical approach to avarana. Int. J. Res. Ayur. Pharm. 2012; 3(6):765-768 